\title{
Anomalous connection of the left hepatic vein to coronary sinus in a child with PAPVD. Surgical significance and diagnostic difficulties
}

\author{
Maciej Aleksander Karolczak, Wojciech Mądry, Ewa Zacharska-Kokot \\ Department of Cardiac Surgery and General Surgery for Children, Medical University of Warsaw, Poland
}

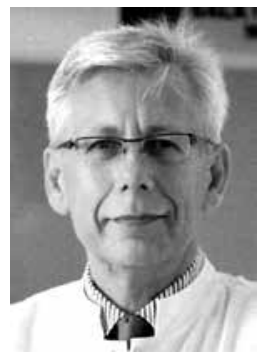

Kardiochirurgia i Torakochirurgia Polska 2016; 13 (1): 49-51

\begin{abstract}
Left hepatic vein (LHV) that drains blood into a coronary sinus (CS) is an extremely rare congenital anomaly of systemic vein drainage with only single reports published. In most of these cases the unusual venous connection was found incidentally during diagnostics or surgery.

The case of a two-year-old boy in whom the anomaly was discovered during open heart surgery for partial anomalous pulmonary venous drainage (PAPVD) is presented. Difficulties in obtaining proper diagnosis preoperatively are confronted with postoperative echo findings.

Embryology and evolution of sinus venosus are discussed to explain the persistent connection between hepatic venous circulation and a coronary sinus. The authors attempt to recapitulate the possible surgical consequences of LHV-CS continuity. Key words: left hepatic vein, coronary sinus anomalies, partial anomalous pulmonary venous drainage.
\end{abstract}

\section{Introduction}

According to Mantini et al. [1], the left hepatic vein (LHV) draining into the coronary sinus (CS) is an extremely rare finding classified as type IA2 of congenital abnormalities involving the coronary sinus. The anomalous vein is usually a single vessel that arises from the left hepatic lobe, passes through the diaphragm and joins the body of the coronary sinus close to its orifice [2]. In most published cases, the anomaly was found incidentally during diagnostic assessment [3-5] or surgery [2]. The anomaly is of no clinical or hemodynamic significance, unless the patient is qualified for heart surgery. We report a case of an anomalous connection of LVH to CS in the child operated on for partial anomalous (right) pulmonary vein drainage (PAPVD).

\section{Streszczenie}

Istnieją jedynie pojedyncze doniesienia opisujące nieprawidłowe połączenie lewej żyły wątrobowej z zatoką wieńcową, które jest skrajnie rzadką anomalią rozwojową układu żył systemowych. W większości przypadków nieprawidłowe połączenie żylne stwierdza się przypadkowo $\mathrm{w}$ trakcie procesu diagnostycznego lub w trakcie operacji.

W pracy zaprezentowano przypadek 2-letniego chłopca, u którego powyższą anomalię odkryto $w$ trakcie korekcji częściowego nieprawidłowego spływu żył płucnych. Autorzy opisują trudności diagnostyczne, konfrontując przed- i pooperacyjne badania echokardiograficzne.

Omówiono embiologię i ewolucję rozwoju zatoki żylnej w celu wyjaśnienia przetrwałych połączeń naczyniowych między żylnym krążeniem wątrobowym a zatoką wieńcową oraz ich możliwe konsekwencje chirurgiczne.

Słowa kluczowe: anomalie zatoki wieńcowej, nieprawidłowy spływ żylny.

\section{Case report}

A two-year-old male patient was admitted for open heart surgery with preliminary diagnosis of a partial anomalous connection of the middle and inferior right pulmonary veins to the right atrium and $9 \mathrm{~mm}$ atrial septal defect (ASD), based on ultrasound and computed tomography (CT) scan evaluation. The transthoracic echocardiography performed in our department found posterior rotation of the right margin of the intraatrial septum resulting in PAPVD, but did not confirm the presence of ASD. The left pulmonary veins as well as right superior pulmonary vein were found to drain in a normal way to the left atrium.

During surgery, while dissecting the inferior vena cava for direct bi-caval cannulation, we found a $5 \mathrm{~mm}$ diame- 
ter vein passing through the diaphragm and draining into the coronary sinus. It was located leftward and parallel to the inferior vena cava (IVC) within the distance of $1.5 \mathrm{~cm}$. Any major tension applied to the vein resulted in cardiac rhythm disturbances and drop in blood pressure.

After commencing moderate hypothermic cardiopulmonary bypass $(\mathrm{CPB})\left(31^{\circ} \mathrm{C}\right)$, the aorta was cross-clamped for a single period of 21 minutes, and the right atrium was opened and inspected. The anomalous vein was controlled with a tourniquet (released every ten minutes). The intracardiac findings consisted of two right pulmonary vein orifices within the right atrium and no atrial septal defect. Ostium of the coronary sinus was markedly enlarged, whereas the orifice of the anomalous (left hepatic) vein was clearly visible in the most distal part of the coronary sinus, close to the right atrial chamber. A large part of the atrial septum was resected and a patch of autogenous pericardium was then used to re-direct the right pulmonary veins to return

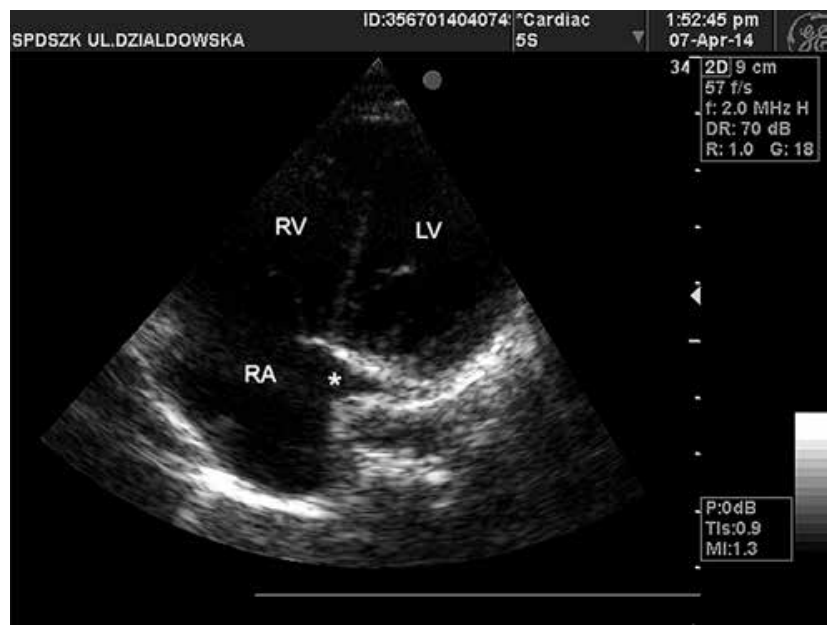

Fig. 1. Apical four chamber view of the heart. Proximal part of coronary sinus is narrow while distal segment is enlarged (asterisk). $\mathrm{RA}$ - right atrium, $\mathrm{RV}$ - right ventricle, LV - left ventricle

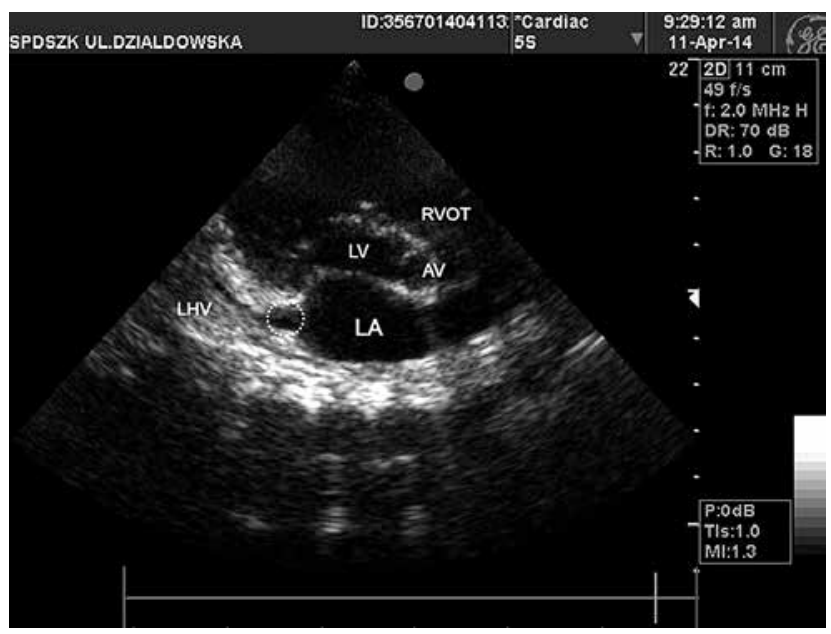

Fig. 2. Modified parasternal short axis view showing transversal cut of distal (ostial) coronary sinus. Left hepatic vein (LHV) joins enlarged coronary sinus (dotted circle). LA - left atrium, LV - left ventricle, RVOT - right ventricle outflow tract, AV - aortic valve to the left atrium. The postoperative period was uneventful and the patient was discharged home on the $9^{\text {th }}$ day after surgery.

Considering the intraoperative findings and possible surgical consequences of unrecognized anomalous connection of the hepatic vein into the coronary sinus, we decided to reevaluate the patient and look for the morphological evidence of the left hepatic vein to the coronary sinus connection. The purpose of this procedure was to determine whether it was possible to make the proper diagnosis prior to surgery. The analysis of preoperative echocardiographic recordings carried out anew did not show the vein directly. It could not be suspected from apparent hemodynamic consequences either. It was most likely due to the markedly increased, turbulent flow caused by an abnormal connection of the right pulmonary veins joining the lowermost part of the right atrium close to the IVC-RA junction and CS ostium. We expected that redirecting the flow from both right pulmonary veins to the left atrium with the patch would diminish blood turbulence within the area of interest and make the task easier. Indeed, the four-chamber apical view revealed the dilatation of the distal (closest to the ostium) part of the coronary sinus, whereas more proximal parts of the CS were normally narrow (Fig. 1). The thorough, gradual inspection of the CS, seen in transverse cut with modified parasternal short axis views, revealed the ostium of the abnormal vein joining the dilated part of the coronary sinus. The $3 \mathrm{~mm}$ diameter vein that originated from the liver, was passing the diaphragm, and joined the coronary sinus perpendicularly (Fig. 2 and 3).

\section{Discussion}

Sinus venosus (SV), which comprises two horns, is located on the caudal end of the primary heart tube and receives blood from three different sources: vitelline or omphalomesenteric veins, umbilical veins, and common

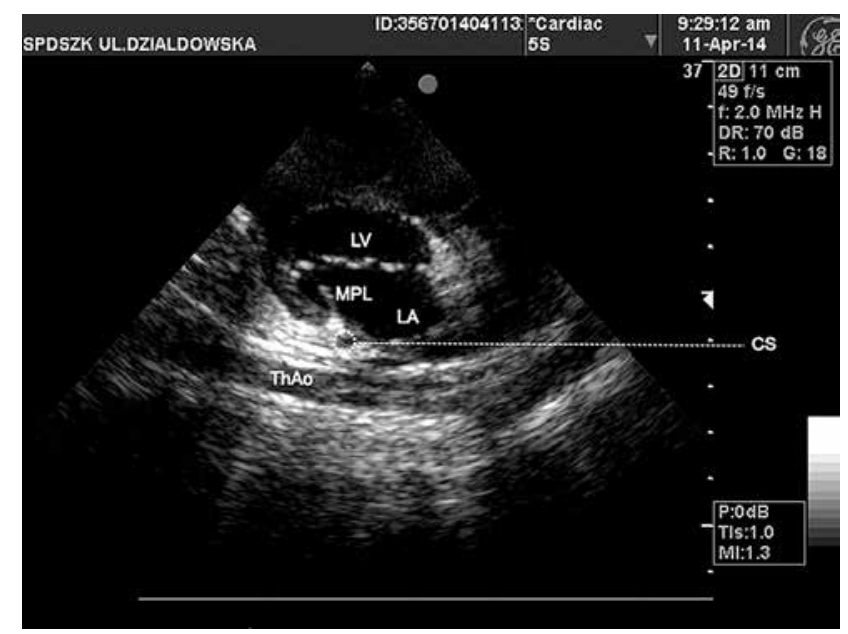

Fig. 3. Modified parasternal short axis view, somewhat more laterally than in Fig. 2. CS - normal sized proximal part of coronary sinus (dotted circle), MPL - posterior leaflet of mitral valve, ThAo - thoracic aorta, LV - left ventricular outflow, LA - left atrium 
cardinal veins. In the complex process of normal heart development, during the $5^{\text {th }}$ week of gestation, the left horn of the sinus venosus is reduced to the coronary sinus and oblique vein of the left atrium. Persistent patency of connections between the left vitelline vein system and left horn of SV could be the main reason for the left hepatic vein to the coronary sinus communication.

Direct venous drainage of a single hepatic vein into the coronary sinus should not have any clinical or hemodynamic consequences. Nevertheless, it has been suggested that it may be associated with atrial arrhythmias and could lead to technical difficulties during coronary sinus approach procedures [3]. While undiagnosed prior to surgery, the anomaly might be found during inspection of the inferior vena cava region either by placing a loop around the vessel, or preparing the site for direct caval cannulation. It is worth mentioning that any excessive tension of LHV should be avoided because of possible rhythm disturbances as well as reduced cardiac output, due to CS blood flow changes. The blood inflow through LVH during the intracardiac procedure is easily controlled by temporary occlusion with tourniquet (like in the reported case), or direct cannulation [2]. The LVH to CS connection is an important issue in patients qualified for Fontan type surgery because of the significant right to left shunt's volume into low-pressure pulmonary venous atrium.

\section{Disclosure}

Authors report no conflict of interest.

\section{References}

1. Mantini E, Grondin CM, Lillehei CW, Edwards JE. Congenital anomalies involving the coronary sinus. Circulation 1966; 33: 317-327.

2. Vuran C, Ozker E, Gumus B, Turkoz R. Anomalous hepatic vein draining into the coronary sinus. Pediatr Cardiol 2011; 32: 1256-1257.

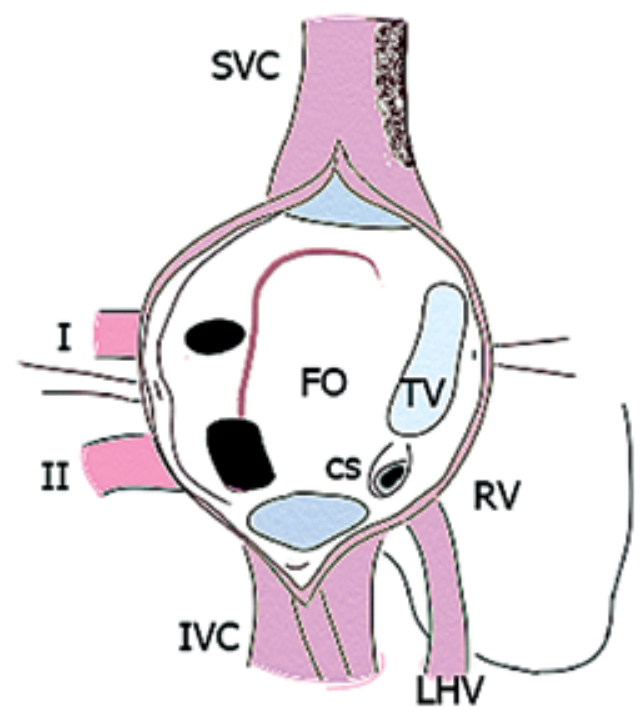

Fig. 4. Schematic representation of morphological findings: SVC - superior vena cava, IVC - inferior vena cava, LHV - left hepatic vein, CS - ostium of coronary sinus, TV - tricuspid valve, FO - fossa ovalis, I - right middle lobe pulmonary vein, II - right inferior lobe pulmonary vein, $\mathrm{RV}$ - right ventricle

3. Lee C, Saremi F. Anomalous left hepatic vein draining into coronary sinus imaged with multidetector computed tomography. Clinical Anatomy 2013; 26: 987-989.

4. van der Horst RL, Winship WS, Gotsman MS. Drainage of left hepatic vein into coronary sinus associated with other systemic venous anomalies. $\mathrm{Br}$ Heart J 1971; 33: 164-166.

5. Buehler M, Abdullah A, Lewis TJ. Left hepatic vein and persistent left superior vena cava drainage into the coronary sinus with subaortic valve stenosis. Int J Angiol 2011; 20: 243-246. 